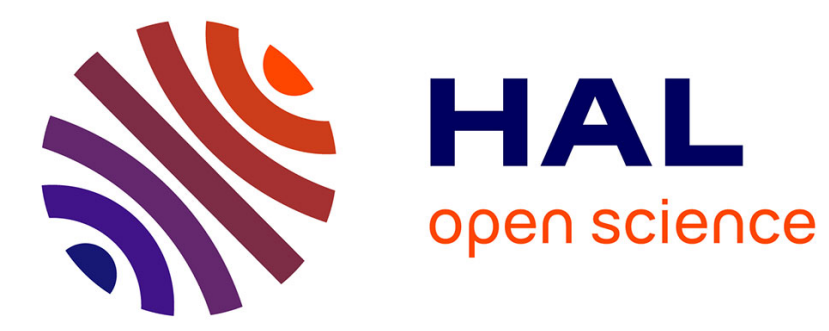

\title{
Efferocytosis of apoptotic HPV positive cervical cancer cells by human primary fibroblasts
}

François Hermetet, Elise Jacquin, Sophie Launay, Emilie Gaiffe, Fabienne Hirchaud, Patrick Sandoz, Jean-Luc Prétet, Christiane Mougin

\section{To cite this version:}

François Hermetet, Elise Jacquin, Sophie Launay, Emilie Gaiffe, Fabienne Hirchaud, et al.. Efferocytosis of apoptotic HPV positive cervical cancer cells by human primary fibroblasts. Biology of the Cell, 2016, 108 (7), pp.189-204. 10.1111/boc.201500090 . hal-01480173

\section{HAL Id: hal-01480173 \\ https://hal.science/hal-01480173}

Submitted on 7 Apr 2017

HAL is a multi-disciplinary open access archive for the deposit and dissemination of scientific research documents, whether they are published or not. The documents may come from teaching and research institutions in France or abroad, or from public or private research centers.
L'archive ouverte pluridisciplinaire $\mathbf{H A L}$, est destinée au dépôt et à la diffusion de documents scientifiques de niveau recherche, publiés ou non, émanant des établissements d'enseignement et de recherche français ou étrangers, des laboratoires publics ou privés. 


\section{Title Page:}

2 Title:

3 Efferocytosis of apoptotic HPV positive cervical cancer cells by human primary fibroblasts

4

5 Short Title:

6 Clearance of apoptotic cancer cells by fibroblasts

7

Authors and Affiliations:

9 François Hermetet $^{1,2}$, Elise Jacquin ${ }^{1,2,3}$, Sophie Launay ${ }^{1,2}$, Emilie Gaiffe ${ }^{1,2}$, Fabienne Hirchaud ${ }^{1,2}$, Patrick 10 Sandoz ${ }^{4}$, Jean-Luc Prétet ${ }^{1,2,5}$, Christiane Mougin $^{1,2,5 \$}$

${ }^{1}$ Univ. Franche-Comté, F-25000 Besancon, France

${ }^{2}$ EA3181, SFRFED4234, LabEx LipSTIC ANR-11-LABX-0021, F-25000 Besancon, France

${ }^{3}$ Signaling ISP, Babraham Institut, Cambridge CB22 3AT, United Kingdom

$15{ }^{4}$ Institut FEMTO-ST, UMR CNRS 6174, Université de Bourgogne Franche-Comté, F-25030 Besancon, France

${ }^{5}$ CHRU Besancon, F-25030 Besancon, France

Address/ phone/ fax/ e-mail of corresponding author:

19 \$ Christiane Mougin, Laboratoire de Biologie Cellulaire et Moléculaire, EA3181-SFRFED4234, Centre Hospitalier Régional Universitaire Jean Minjoz, Boulevard Alexandre Fleming, 25030 Besançon cedex, France,

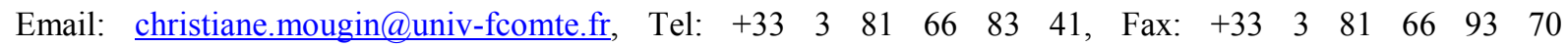




\section{Abstract:}

Efficient clearance of dying cells is a fundamental physiological process for tissue development and homeostasis. The contribution of amateur phagocytes like fibroblasts to apoptotic cell efferocytosis has been established though the underlying mechanisms are not well understood. We recently demonstrated that horizontal DNA transfer can occur through the uptake of apoptotic HPV positive cancer cells by human primary fibroblasts (HPFs) leading to their transformation. In the present study, by using in vitro co-culture approaches, we confirm the role of HPFs as non-professional phagocytes in the context of apoptotic cervical cancer cell removal. Confocal microscopy imaging and flow cytometry analyses revealed that HPFs engulf more efficiently late apoptotic cells than early apoptotic targets, but their phagocytic ability remains limited compared to professional phagocytes as human monocytes-derived macrophages. Efferocytosis by HPFs occurs in a time-, temperature- and calcium-dependent manner. Remodeling of actin-fibers contributes to the biogenesis of macroendocytic vacuoles. Both morphological analyses and pharmacological approaches confirmed the involvement of actin driven-phagocytosis and likely -macropinocytosis in apoptotic target internalization by HPFs. The uptake of apoptotic cell requires phosphatidylserine recognition. In HPFs, immunofluorescence and functional experiments using specific RNA interference assay suggested that this recognition is mainly mediated by Brain-specific Angiogenesis Inhibitor-1 (BAI1) and that this receptor contributes to subsequent uptake orchestration. Confocal microscopy analyses with organelle-specific markers revealed that internalized apoptotic material traffics into late phagolysosomes and specific-features of Microtubule-associated protein 1 Light Chain 3 alpha (LC3)-associated phagocytosis are observed. We conclude that efferocytosis by HPFs is mediated by phagocytosis/macropinocytosis involving phosphatidylserine recognition likely by the phosphatidylserine receptor BAI1. 
46 Keywords:

47 Human primary fibroblasts, Efferocytosis, Apoptosis, Apoptotic cervical cancer cells, Phosphatidylserine, Brain48 specific 
Introduction:

Clearance of apoptotic cells (AC), so-called efferocytosis, largely contributes to tissue homeostasis in vivo. Although this fundamental physiological process is a property of most cell types [1-6], macrophages are the main and most effective phagocytes for the removal of AC. They have been widely used to investigate the molecular mechanisms underlying recognition, uptake, and degradation of $\mathrm{AC}[1,2,4,6-10]$.

The recognition of $\mathrm{AC}$ by macrophages involves numerous receptors expressed on macrophage cell surface that bind their specific ligands exposed on $\mathrm{AC}$ and referred to as "Eat me" signals $[1,2,6,11,12]$. To date, various "Eat me" signals have been described including altered sugars, lipids and proteins [6] but Phosphatidylserine (PtdSer) is the best-studied [13-17]. Previous publications support the importance of PtdSer receptors, including T cell Immunoglobulin-and-mucin domain Molecule (TIM), Brain-specific Angiogenesis Inhibitor 1 (BAI1), and stabilin-2, in the clearance of AC through the direct recognition of externalized PtdSer on the AC surface [18-23]. TIM-4, highly expressed by macrophage cell lines, is a small transmembrane protein that binds PtdSer via its immunoglobulin domain $[19,24]$. Bone marrow-derived macrophages from TIM-4-/mice were recently reported to have a highly reduced ability to engulf apoptotic bodies or PtdSer-bearing targets $[25,26]$. Such observations suggest that TIM-4 is the primary receptor for PtdSer in those professional phagocytosis models. BAI1, another PtdSer receptor, is a seven transmembrane receptor that belongs to a subfamily of adhesion G-protein-coupled receptors [27]. The first recognized function of BAI1 was its ability to inhibit angiogenesis and tumor formation through the proteolytic processing of its $\mathrm{N}$-terminal domain into secreted vaculostatins [28-30]. BAI1 is expressed in macrophage cell lines and immunological tissues such as the bone marrow and spleen and is known to contribute to AC phagocytosis and myoblast fusion via its thrombospondin (TSP) type 1 repeats [21, 31]. Other receptors [e.g. vitronectin receptor ( $\alpha \mathrm{v} \beta 3$ integrin), Mer tyrosine kinase family (MerTK, Tyro3 and Axl)] are involved in indirect recognition of PtdSer and require soluble bridging proteins [e.g. TSP 1 or Milk Fat Globule-EGF factor 8 (MFG-E8), Gas6 or protein S] [6].

Engagement of the PtdSer receptors initiates signaling events within the phagocyte. The Rho-family GTPases are prominent players in the transmission and integration of signals and activate actin-related protein2/3 (Arp2/3) complex, formins and WH2 domain-containing nucleators [32-34]. This leads to actin cytoskeleton remodeling, engulfment of dead cells into macroendocytic vacuole [1, 21, 35].

Regarding the internalization of dead cells by professional phagocytes, different mechanisms are now being appreciated, even if information about their target cell specificity (apoptotis and necrosis) remains sparse 
(reviewed in Ref. [36]). Indeed, several observations indicate that the interaction of macrophages with dead cells initiates internalization of the targets, and that internalization can be preceded by phagocytosis "zipper"-like mechanism (i.e. related to a formation of a close-fitting phagocytic cups) or macropinocytotic mechanism (i.e. related to a formation of spacious macropinosomes accompanied by ruffling of the ingesting macrophages).

During macroendocytic maturation, their membrane fuses with intracellular organelles including early endosomes, late endosomes and lysosomes [37-39]. Recently, Martinez and colleagues highlighted that efficient clearance of $\mathrm{AC}$ by macrophages involves the recruitment and lipidation of Microtubule-associated protein 1 light chain 3 alpha (LC3) to the AC-containing phagosome membrane followed by an acidification of the phagocytic vacuole [25]. Authors suggested that during this process named LC3-associated phagocytosis (LAP), LC3 facilitates the phagosome maturation and the degradation of cellular corpses.

AC clearance by non-specialized phagocytic cells has been investigated in a limited number of studies [40-45], the results of which suggest that mechanisms underlying prey cell recognition and clearance may differ from those observed in professional phagocytes $[1,2,5,11]$.

Through the endocytic process, AC can act as a DNA vector that may confer a selective advantage to the recipient cell $[46,47]$. In a previous study, we provided evidence of an engulfment of apoptotic human cervical cancer-derived cells by human primary fibroblasts (HPFs) [48]. Apoptotic HPV-positive cells ensured a horizontal transfer of oncogenes to HPFs revealed by in situ hybridization and PCR analyses. HPFs subsequently expressed HPV E6 mRNA and exhibited transformed cell properties such as increased proliferation, anchorageindependent growth capacity and aneuploidy. The results highlighted an alternative mechanism of HPVassociated carcinogenesis from mesenchymal cells that are not natural targets of HPV [48-50].

In the present study, we have analyzed mechanisms that drive non-professional phagocytes, namely HPFs, to clear apoptotic HPV-positive cervical cancer cells. By using flow cytometry, confocal imaging and functional studies, we show that HPFs are able to phagocytize dead tumor cell corpses by recognizing and binding PtdSer thanks to the specific receptor BAI1 expressed by HFP, engaging actin-fibers remodeling to the macroendocytic vacuole formation and tranlocating LC3 for its maturation. 


\section{Results:}

\section{Characterization of apoptotic cell death}

The apoptosis of cervical carcinoma donor cells was induced by ultra-violet (UV)-B exposure followed by staurosporine (STS) treatment for $6 \mathrm{~h}$ and $48 \mathrm{~h}$ as previously described [48]. To ensure that only dying and dead cells were used for endocytosis assays, sloughed cells were collected and characterized by apoptosis assays. By contrast, viable HeLa and Ca Ski used as untreated cell controls were harvested by trypzinisation. As shown by Sub-G1 analysis, the percentage of cells with fragmented DNA increased in a time-dependent manner; no obvious feature of apoptosis or hypodiploid cells was detected in untreated cells (Figure 1A). Apoptosis was further confirmed by specific nuclear morphology changes evidenced by DAPI staining (Figure 1B). Flow cytometry analysis demonstrates that treatment for $6 \mathrm{~h}$ resulted in an increase of early apoptotic cells (EAC) defined as annexin $\mathrm{V}$ single-positive $(74.2 \% \pm 3.8$ for HeLa; $80.8 \% \pm 1.0$ for Ca Ski) and treatment for $48 \mathrm{~h}$ resulted in a high rate of late apoptotic cells (LAC) defined as annexin V and PI double-positive (97.0\% \pm 1.9 for HeLa; 88.6\% \pm 3.9 for Ca Ski) (Figure 1C).

\section{Late apoptotic cells are preferentially engulfed by HPFs}

To establish the extent to which HPFs could engulf apoptotic cervical carcinoma HeLa and Ca Ski cells regardless of various stages of apoptosis, HPFs were co-cultured with PKH67-labeled EAC or LAC, washed twice to remove adherent cells, fixed in PFA, and labeled with phalloidin-TRITC and DAPI. Based on confocal microscopy analysis, unloaded HPFs could be clearly distinguished from HPFs having ingested early or late PKH67-labeled apoptotic HeLa or Ca Ski cells. Figure 2A is representative of confocal microscopy images of co-culture. It has been established that late apoptotic/necrotic cells induce phagocyte activation, whereas early apoptotic cells do not [3]. As might be expected, the engulfment of EAC analyzed by confocal microscopy was much less efficient than that of LAC (Figure 2A and B). Indeed, although EAC and LAC were co-cultured with HPFs at similar ratio (10:1), most of EAC were released following washing and the remaining cells mostly displayed cell-cell contact but were not phagocytosed as shown in Figure 2A, left panel. The 6 h co-culture duration was chosen for further experiments in order to maintain transient nature of the early apoptotic signature throughout period of co-culture and to avoid appearance of LAC [51]. LAC were mostly engulfed by HPFs, as soon as $2 \mathrm{~h}$ of co-culture (Figure $2 \mathrm{~B}$ ), as demonstrated by the presence of scattered yellow/green $\mathrm{AC}$ within the red HPFs (Figure 2A, middle panel). This result demonstrates that cell fragments (1 to $10 \mu \mathrm{m}$ in diameter) were 
unequivocally inside the HPFs. Moreover, the human monocytes-derived macrophages $(\mathrm{M} \varphi)$, serving as professional phagocyte controls, exhibited their high capacity for the uptake of LAC compared to HPFs (Figure 2A, right panel).

Using the quantitative flow cytometry approach, we assessed the percentage of PKH26-stained HPFs that engulfed PKH67-stained apoptotic cancer cells at early time periods ( $2 \mathrm{~h}$ and $6 \mathrm{~h}$ ) of co-culture. As shown by the appearance of PKH67- and PKH26 double- positive populations (Figure 2C), the cytometry analyses confirmed the rate of $\mathrm{AC}$ uptake by HPFs observed by microscopy (Figure 2C and D). Taken together, these results show that HPFs clearly distinguished EAC and LAC and that their phagocytic capacity was limited to apoptotic subcellular fragments (LAC), which is consistent with their non-professional nature [40].

We next studied the kinetics of $\mathrm{AC}$ internalization by HPFs and $\mathrm{M} \varphi$ by varying the exposure time (2 $72 \mathrm{~h}$ ) of LAC to the phagocytic cells. Again, the phagocytic capacity was defined as the percentage of HPFs and $\mathrm{M} \varphi$ that engulf LAC. Figure 2E indicates that HPFs and M $\varphi$ reached their maximum phagocytic capacity at $24 \mathrm{~h}$ post-exposure. Nevertheless, the percentage of phagocytosing HPFs was less compared to M $\varphi$ (Figure 2E). In total HPFs engulfed AC with a lower efficiency than M phagocyte nature [52].

Moreover, we studied in detail morphological aspects of dead cell engulfment by HPFs using confocal microscopy (Figure 2F). The reorganization of the actin cytoskeleton observed during internalization of doublePKH67/DAPI-labeled LAC suggests both phagocytosis and macropinocytotic process. During the initial step of endocytosis, LAC bound to the plasma membrane. Actin polymerization was localized underneath the plasma membrane in contact with LAC to be ingested, and dense network of actin filaments appeared in this region (Figure 2Fa). Then membranous expansions extended around the dead cell (Figure 2Fb) to ultimately engulf it (Figure 2Fd). Macropinocytosis-like movements were also observed (Figure 2Fc). The ingested LAC was completely enclosed into HPFs within $6 \mathrm{~h}$, in a membrane-bound vacuole (Figure 2Fe and f).

In addition, the monitoring of $\mathrm{AC}$ clearance was evaluated by position-referenced microscopy as we published [53]. By tracking the fluorescent dyes during co-culture between PKH26-labeled HPFs and CFSElabeled HeLa LAC at different time periods, we observed that apoptotic corpses quickly adhered (1 h) to the plasma membrane of HPFs and were efficiently internalized by HPFs within $6 \mathrm{~h}$ after first tethering (Figure 2G and Figure S1). These time-lapse events have been already described for other non-professional phagocytes [42, 52]. 
Clearance of LAC by HPFs is inhibited by low temperature incubation, EDTA, cytochalasin D and dimethylamiloride

The surface morphology as visualized by confocal microscopy revealed dynamic actin-based membrane protrusions of HPFs that induce phagocytic cup formation during the process of AC internalization. To better understand the type of endocytosis used by HPFs to engulf AC, we tested physical and chemical inhibitors. When recipient cells were co-incubated with $\mathrm{HeLa}$ and $\mathrm{Ca}$ Ski AC at $4^{\circ} \mathrm{C}$ or in the presence of $2 \mathrm{mM}$ EDTA, the percentage of internalization significantly dropped to $2 \%$ suggesting that internalization requires energy and divalent ions $\left(\mathrm{Ca}^{2+}, \mathrm{Mg}^{2+}\right)$ (Figure 3A). Cytochalasin D (a F-actin depolymerizing agent) or dimethylamiloride (DMA; an inhibitor of $\mathrm{Na}^{+} / \mathrm{H}^{+}$exchange that prevents membrane ruffling and macropinocytosis) have been used to treat HPFs prior to the addition of LAC. These treatments resulted in significant decreases of LAC uptake by HPFs in a dose-dependent manner, suggesting the involvement of phagocytosis and/or macropinocytosis in the internalization process (Figure 3A). A partial inhibition of LAC uptake was seen using chlorpromazine (an inhibitor of clathrin-dependent endocytosis) at a concentration of $20 \mu \mathrm{M}$. By contrast nystatin (an inhibitor of caveolin-dependent endocytosis) had no effect on the uptake of LAC whatever the concentration used (Figure clearance.

3A). Taken together, these data suggest the main contribution of phagocytosis and macropinocytosis in AC

It is noteworthy that $6 \mathrm{~h}$ treatment with high concentrations of cytochalasin $\mathrm{D}(>4 \mu \mathrm{M})$, DMA $(>80$ $\mu \mathrm{M})$, chlorpromazine $(>20 \mu \mathrm{M})$ and nystatin $(>20 \mu \mathrm{M})$ interfered with HPFs viability, as monitored by MTT test (Figure S2), and were not considered for internalization assays.

\section{Efferocytosis of LAC by HPFs is partially mediated by phosphatidylserine and BAI1}

Phosphatidylserine (PtdSer) exposure is widely considered as a canonical marker of apoptosis. The contribution of PtdSer recognition by HPFs was evaluated by measuring the ability of HPFs to engulf PKH67$\mathrm{AC}$ incubated with an excess of annexin V. Pretreatment with 40 and $160 \mu \mathrm{g} / \mathrm{mL}$ of annexin V efficiently block PtdSer recognition (Figure 3B) and resulted in a dose-dependent decrease of LAC uptake by HPFs (Figure 3C). Four main PtdSer receptors have been shown to be involved in the uptake of AC by professional phagocytes: BAI1, TIM-1, TIM-4 and Stabiline $2[1,5]$. Among these 4 different PtdSer receptors, we noted that 2 were expressed by M $\varphi$, namely BAI1 and TIM-4 as shown in RT-qPCR analysis (Figure 3D). The receptors involved in endocytosis of AC by amateur phagocytes have not been clearly identified. Here, HPFs expressed only $B A I 1$ that displayed lower levels of mRNA compared to $\mathrm{M} \varphi$ (Figure 3D). Moreover, immuno-localization studies with 
the H270 antibody indicated that BAI1 was not uniformly distributed but showed a variable and patchy membrane staining in HPFs, as well as in $\mathrm{M} \varphi$, in absence of apoptotic cells (Figure 3E). During co-culture between HPFs and AC, BAI1 showed a tendency to accumulate within the phagocytic cup (Figure 3F). We raised the hypothesis that fibroblastic BAIl may subserve an engulfment function of apoptotic corpses. To assess the function of BAIl in this system we performed short interference RNA (siRNA) transfection in HPFs prior to co-culture as described in detail in material and methods. This resulted in a significant decrease of human BAI1 mRNA levels (Figure 3G). Compared to siRNA negative control, HPFs transfected with BAI1 siRNA demonstrated a lower ability to internalize PKH67-labeled LAC, either HeLa or Ca Ski LAC (Figure 3H). Thus we believe BAI1 to be a surrogate molecule to engulf apoptotic targets.

\section{Recruitment of LC3 onto the phagocytic vacuole occurs after LAC efferocytosis by HPFs}

Some components of the autophagy machinery being involved in the maturation of macroendocytic vacuoles $[25,54,55]$, we further sought to assess the recruitment of LC3 and LAMP-1 to macroendocytic vacuoles after AC engulfment by HPFs. Western blotting analyses revealed that HPFs co-cultured with LAC contained higher levels of the lipidated LC3 form (LC3-II) compared to control cells suggesting that LAC uptake led to LC3-II conversion in HPFs (Figure 4A). Confocal microscopy analyses of LC3 immunostaining after cell fixation showed that LC3 could be recruited to AC-containing vacuole (Figure 4B). Thus, LC3-II conversion after AC uptake might be at least partly associated to the direct LC3 lipidation onto macroendocytic vacuole. Taken together, these results indicate that AC uptake by HPFs can initiate LC3-associated phagocytosis as previously described in macrophages $[25,54,55]$. Furthermore, a positive staining of some macroendocytic vacuoles with Lysosomal-associated membrane protein 1 (LAMP-1), a classical marker of lysosomal compartments [56, 57], suggest a fusion of AC-containing vacuoles with lysosomes (Figure 4B). Further work is necessary to establish fully the significance of these observations. 


\section{Materials and Methods:}

\section{Cell culture}

HeLa (HPV18 DNA-positive) and Ca Ski (HPV16 DNA-positive) cervical cancer cell lines were obtained from American Type Culture Collection (Rockville, MD, USA) and used to generate early (EAC) or late (LAC) apoptotic cells. They were maintained as previously described [58].

Human primary fibroblasts (HPFs) were isolated from surgical residues which are not subject to validation from an ethics committee and patient's consent in accordance with the law L.1245-2 of the "Code de la santé publique" applied in France. However, the laboratory that provided HPFs has documents stating the patient's non-opposition to the use of surgical residues for medical research in accordance with the law L.1211-2. HPFs were grown at $37^{\circ} \mathrm{C}\left(5 \% \mathrm{CO}_{2}\right)$ in complete DMEM L-glutamine (Lonza, Basel, Switzerland) supplemented with $10 \%$ fetal bovine serum (FBS; Lonza) and $10 \times 10^{4} \mathrm{U} / \mathrm{L}$ penicillin/streptomycin (Lonza).

Human monocytes were isolated and purified from peripheral blood mononuclear cells (PBMC) of buffy coat from healthy volunteers (Etablissement Français du Sang) using Ficoll-Hypaque (GE Healthcare, Orsay, France). After isolation from PBMC using a CD14+ selection kit (Miltenyi Biotech, Paris, France), monocytes were differentiated into human monocyte-derived macrophages $(\mathrm{M} \varphi)$ by culturing cells at $1 \times 10^{6}$ cells/mL in a 24-well plate for 7 days in RPMI (Gibco, Life Technologies) supplemented with 10\% FBS (Gibco) and $50 \mathrm{ng} / \mathrm{mL}$ macrophage colony-stimulating factor (M-CSF; Miltenyi Biotech). Non-adherent cells were removed by washing prior experiments.

Cells were routinely checked for mycoplasm contamination.

\section{Generation of apoptotic cells}

Twenty-four hours prior to apoptosis induction, cancer cells were seeded at $5 \times 10^{4}$ cells $/ \mathrm{cm}^{2}$ and apoptosis was induced with UV-B irradiation (UV cross-linker, Ultra-Violet Products Ltd., Cambridge, UK) (20 $\mathrm{mJ} / \mathrm{cm}^{2}$ ) followed by $300 \mathrm{nM}$ staurosporine (STS; Sigma-Aldrich, St. Quentin Fallavier, France) treatment for the indicated time periods. Cells (viable and apoptotic) were then washed twice thoroughly with Phosphate Buffered Saline (PBS; Lonza) before apoptosis assays and endocytosis assays described thereafter.

\section{Confocal microscopy}

Apoptosis detection. For imaging analysis, apoptotic cells were dropped on polysine ${ }^{\circledR}$ microscope slides (ThermoScientific, Illkirch, France), washed with PBS and fixed with $3.7 \%$ (w/v) paraformaldehyde 
(PFA; Sigma-Aldrich) for $10 \mathrm{~min}$ at room temperature (RT). DNA from apoptotic cells was stained with $300 \mathrm{nM}$ 4',6-diamidino-2-phenylindole, dihydrochloride (DAPI; Invitrogen, Life Technologies, St. Aubin, France) for 5 min at RT. After an ultimate washing with PBS, glass coverslips of $1.9 \mathrm{~cm}^{2}$ (Dutscher, Brumath, France) were mounted on slides in Vectashield Mounting Media for Fluorescence (VectorLabs, Burlingame, California, USA). Cells were finally examined by fluorescent confocal microscopy using the Olympus FluoView 1000 (Olympus, Tokyo, Japan) with appropriate filter settings and 40X/1.0 or 100X/1.0 numeric aperture oil objectives. Images were captured and data were generated using the Olympus FluoView10-ASW (Version 4.2) software.

Endocytosis assay. HeLa and Ca Ski cells were fluorescently labeled with PKH67 (green) prior to apoptosis induction according to the manufacturer's instructions (PKH67-Fluorescent Cell Linker Kits for General Cell Membrane Labeling; Sigma-Aldrich). In brief, $10^{7} \mathrm{HeLa}$ or Ca Ski cells/mL were washed in serumfree culture medium and resuspended in $2 \mathrm{~mL}$ PKH67-containing Diluent $\mathrm{C}\left(2 \times 10^{-6} \mathrm{M}\right)$ for 4 min at RT. Non-

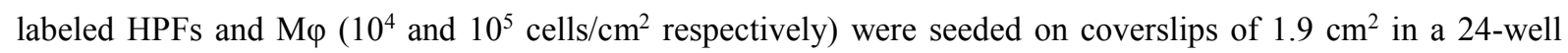
plate. Then PKH67-labeled apoptotic cells were co-cultured with HPFs or M $\varphi$ at a 10:1 ratio for different time periods at $37^{\circ} \mathrm{C}$ in $500 \mu \mathrm{L}$ DMEM according to our previous data [48]. Coverslips were washed twice with PBS to remove the non-ingested apoptotic cells. HPFs or M $\varphi$ were fixed with $3.7 \%(\mathrm{w} / \mathrm{v}) \mathrm{PFA}$. F-actin was stained with phalloidin-tetramethylrhodamine-isothiocyanate (TRITC) (Sigma-Aldrich) $\left(2.5 \times 10^{-2} \mathrm{~g} / \mathrm{L}\right)$ for $30 \mathrm{~min}$ at $4^{\circ} \mathrm{C}$ and DNA was stained with $300 \mathrm{nM}$ DAPI for 5 min at RT. Cells were finally examined and images captured as described above. For each condition, more than 200 HPFs or M $\varphi$ were randomly observed and scored by two independent blinded observers.

Uptake of apoptotic cells by HPFs was also investigated by position-referenced microscopy to track the fate of HPFs exposed to apoptotic cells, as we previously described in detail [53]. Briefly, (5-(and 6-)carboxyfluoresceine diacetate succinimidyl ester- (CFDA, SE; Invitrogen) labeled apoptotic cells were incubated with PKH26-labeled HPFs for $11 \mathrm{~h}$ with an observation every hour. Images recorded at different instants in time are superimposed in a common coordinate system with subpixel accuracy.

Fluorescent staining. Fluorescence analyses were performed as described above using Cell Proliferation Dye eFluor ${ }^{\circledR} 450$ (eBioscience, San Diego, CA, USA), phalloidin-TRITC, Rabbit monoclonal anti-BAI1 [SC66815 _ Anti-Mouse, Rat, Human, BAI-1 (H270), Santa Cruz Biotechnology, Inc., Dallas, Texas, USA], rabbit polyclonal anti-LC3A/B (\#4108, Cell Signalling Technology, Danvers, MA, USA), mouse anti-LAMP1 (CD107a, BD Pharmingen, BD Biosciences, Le Pont de Claix, France) primary antibodies, and DAPI according 
to the manufacturer's recommendations. For immunostaining, primary antibodies and goat-anti-rabbit-Alexa488and donkey-anti-mouse-Cy'TM- (Jackson ImmunoResearch Laboratories, Inc, West Grove, PA, USA) conjugated secondary antibodies were used diluted at 1:100 and 1:250 respectively.

\section{Flow cytometry}

Apoptosis detection. For sub-G1 analysis, cells were fixed overnight in ice-cold $70 \%$ ethanol. After washing with PBS, cells were incubated with propidium iodide (PI; BD Pharmingen) (10 $\mu \mathrm{g} / \mathrm{mL})$ in PBS supplemented with DNase-free RNase A (Thermo Fisher Scientific, Waltham, USA) (1 mg/mL) in darkness for $15 \mathrm{~min}$ at RT. The intracellular PI fluorescence intensities of 20,000 cells were measured for each sample using the FC500 flow cytometer (Beckman Coulter, Orange County, CA, USA). The cytometry analyses were performed using CXP software (Beckman Coulter). For the annexin V/PI apoptosis assay, the cells were stained with fluorescein isothiocyanate (FITC) annexin V from Apoptosis Detection Kit I (BD Pharmingen) and PI in darkness for 15 min at RT, resuspended in binding buffer and analyzed by flow cytometry according to the manufacturer's instructions.

Endocytosis assay. HeLa and Ca Ski cells were fluorescently labeled with PKH67 (green) prior to apoptosis and HPFs were labeled with PKH26 (red) according to the manufacturer's instructions (PKH26Fluorescent Cell Linker Kits for General Cell Membrane Labeling; Sigma-Aldrich). HPFs were seeded at $10^{4}$ cells $/ \mathrm{cm}^{2}$ in a 24-well plate. Then PKH67-labeled HeLa or Ca Ski were co-cultured with 20,000 PKH26-labeled adherent HPFs at a 10:1 ratio for different time periods in the conditions described previously [48]. HPFs incubated with apoptotic cells were harvested by trypsinization and engulfment was assayed using 2-color flow cytometry. The percentage of PKH26-positive cells stained positive for PKH67 was considered as the proportion of HPFs having ingested apoptotic cells. Appropriate controls were performed to set the cytometer for each color. When indicated, culture or co-culture conditions were modified prior to endocytosis assays. A PtdSer masking assay was performed to assess the contribution of the PtdSer exposed by LAC in their uptake by HPFs. Briefly, late apoptotic cells (LAC) were pre-incubated in binding buffer with 40 or $160 \mu \mathrm{g} / \mathrm{mL}$ unlabeled purified recombinant annexin V (BD Pharmingen) at RT for $30 \mathrm{~min}$, before being used in flow cytometry endocytosis assays. To quantify the saturation rate of annexin $\mathrm{V}$ specific binding sites, a fraction of preincubated cells were incubated with phycoerythrin (PE) annexin V (BD Pharmingen) at RT for 30 min. Titration of blocked annexin $\mathrm{V}$ binding sites was performed by flow cytometry analysis. HPFs were pre-incubated with Ethylene diamine tetraacetic acid (EDTA) disodium salt (Lonza) (up to $2 \mathrm{mM}$ ), cytochalasin D (Sigma-Aldrich) (up to $4 \mu \mathrm{M}$ ), 5-(N,N-dimethyl)amiloride hydrochloride (DMA; Sigma-Aldrich) (up to $80 \mu \mathrm{M}$ ), chlorpromazine 
(Sigma-Aldrich) (up to $20 \mu \mathrm{M}$ ) and nystatin (Sigma-Aldrich) (up to $20 \mu \mathrm{M}$ ) at $37^{\circ} \mathrm{C}$ for $1 \mathrm{~h}$ before performing flow cytometry endocytosis assays at $37^{\circ} \mathrm{C}$ [59]. In additional experiments, HPFs were co-incubated with apoptotic targets at $4^{\circ} \mathrm{C}$. Moreover, BAI1 siRNA (On-TargetPlus SMART pool; Dharmacon, Lafayette, CO, USA) and siRNA negative control (Eurogentec, Angers, France) were introduced into HPFs by transfection (Lipofectamine ${ }^{\circledR} 2000$; Life Technologies) $48 \mathrm{~h}$ before exposure to LAC. In brief, $50 \mu \mathrm{M}$ siRNA were added to $2 \times 10^{4}$ cells incubated in Opti-MEM (Life Technologies). RNA was prepared to assess the level of BAI1 expression by Real-time RT-PCR (RT-qPCR) analysis.

\section{RNA isolation and real-time RT-PCR analysis}

RNA was extracted from $10^{6}$ cells using the QIAamp® RNA Blood Mini Kit (Qiagen, Courtaboeuf, France) according to the manufacturer's recommendations. Contaminant genomic DNA was removed by a treatment with $0.2 \mathrm{U} / \mu \mathrm{L}$ of DNase I Amplification Grade (Invitrogen, Cergy Pontoise, France) before reverse transcription with $500 \mathrm{ng}$ of RNA using the SuperscriptVILO cDNA Synthesis Kit (Life Technologies).

Quantitation of BAI1, TIM-4, and human $\beta-2-$ microglobulin (B2M) transcripts was performed with a 7500 Real Time PCR System (Applied Biosystems, Life Technologies) in the 1X TaqMan Gene Expression Master Mix (Applied Biosystems), using respectively the Hs01105174_m1 and Hs00293316_m1 Assays-onDemand $^{\mathrm{TM}} \quad$ (Applied Biosystems) or $500 \mathrm{nM}$ of each primer (forward primer: GATGAGTATGCCTGCCGTGTG; reverse primer: CAATCCAAATGCGGCATCT, Eurogentec) and $200 \mathrm{nM}$ of probe (6-FAM-CCT-CCA-TGA-TGC-TGC-TTA-CAT-GTC-TCG-1TC-CC-BHQ-1, Eurogentec) targeting the B2M. RT-qPCR were performed in $20 \mu \mathrm{L}$ of a reaction mixture containing $4 \mu \mathrm{L}$ of diluted cDNA (1:5) with 45 amplification cycles $\left(95^{\circ} \mathrm{C}\right.$ for $15 \mathrm{sec}, 60^{\circ} \mathrm{C}$ for $\left.1 \mathrm{~min}\right)$. Relative quantitation of mRNA was performed according to the $2^{-\Delta \Delta \mathrm{Ct}}$ method algorithm with B2M serving as housekeeping control and 5 serial dilutions $(1: 10)$ cDNA from $\mathrm{M} \varphi$ as calibrator.

\section{Western blotting}

Western blotting was performed as described previously [48]. Cells were collected in RIPA lysis buffer (50 mM Tris/HCl, pH 7.4, 150 mM NaCl, 1\% Nonidet P-40, 0.5\% Na deoxycholate, 1 mM EDTA) containing anti-proteases $(30 \mu \mathrm{g} / \mathrm{mL})$ (Roche) and proteins were extracted from whole cells. Protein concentrations were quantified using the Biorad Protein Assay® (BioRad Laboratories, Hercules, CA, USA) according to the manufacturer's instructions. Thirty $\mu \mathrm{g}$ of proteins were boiled in Laemmli's buffer (BioRad Laboratories) supplemented with $5 \% \quad \beta$-mercaptoethanol and run on $15 \%$ SDS-polyacrylamide gel. Proteins were then electrotransferred onto Hybond ${ }^{\mathrm{TM}}$-P PVDF membranes (Amersham Pharmacia Biotech Europe GmbH, Saclay, 
France), probed overnight with rabbit polyclonal anti-LC3A/B (\#4108) and mouse monoclonal anti- $\beta$-actin (clone AC15, Sigma-Aldrich) diluted at 1:1000 or 1:10,000 respectively according to the manufacturer's instructions. After washing, immune complexes were revealed with horseradish peroxidase-(HRP) conjugatedgoat-anti-rabbit Ig and goat-anti-mouse Ig antibodies (BD Biosciences) for $1 \mathrm{~h}$ diluted at 1:8000 or 1:20,000 respectively. The reaction was visualized using ECL reagents (Pierce ECL2 Western Blotting Substrate, ThermoScientific) according to the manufacturer's instructions and images were captured with a charge-coupled device (CCD) camera of the imaging system Chemidoc XRS+ (Bio-Rad Laboratories). Band density was quantified by Image Lab software (Bio-Rad Laboratories) and normalized to the loading control ( $\beta$-actin). The resulting values from three different experiments were expressed as LC3II/LC3I ratio respect to the control value and reported under the western blotting as mean values \pm standard deviation (SD).

\section{Statistical analysis}

Data are expressed as means $\pm \mathrm{SD}$ of at least nine measurements (corresponding to experiments performed independently at least three times in triplicate). P values were analyzed using the Wilcoxon test. Statistical analysis was done using GraphPad Prism (GraphPad Software, San Diego, CA). Significant differences between the groups are indicated as $* \mathrm{p}<0.05, * * \mathrm{p}<0.01$ and $* * * \mathrm{p}<0.001$.

\section{Cell viability assay (supplementary method)}

HPFs were seeded in 96-well plates (3000 cells/well) with $100 \mu \mathrm{L}$ of complete medium/well $24 \mathrm{~h}$ prior to EDTA or chemical inhibitors of endocytosis treatment and incubated for $6 \mathrm{~h}$ at $37^{\circ} \mathrm{C}$. Then $10 \mu \mathrm{L}(5 \mathrm{mg} / \mathrm{mL})$ of MTT (Cell Proliferation Kit I, Roche Diagnostics, Meylan, France) solution was added to each well. After 4 h, $100 \mu \mathrm{L}$ of solubilization solution $(10 \% \mathrm{SDS}$ in $0.01 \mathrm{M} \mathrm{HCl})$ were added to each well, and cells were incubated overnight. Absorbance at $570 \mathrm{~nm}$ wavelength was measured with a $665 \mathrm{~nm}$ reference wavelength using the scanning multiwell spectrofluorimeter EnVision 2012 Multilabel Reader (PerkinElmer, Courtaboeuf, France). 


\section{Discussion:}

In vivo, the rapid and efficient clearance of dying cells is fundamental for tissue development and homeostasis as well as protection against chronic inflammation and autoimmunity. As typical professional phagocytes, macrophages play a central role in the efferocytosis process. Over the last few decades, it has become clear that epithelial cells, endothelial cells, smooth muscle cells, and fibroblasts, namely nonprofessional or amateur phagocytes may contribute to dying cell clearance $[1,2,40-45,52]$. With regard to fibroblasts, they are known to be involved in a variety of physiological (e.g. deposition of extracellular matrix, regulation of epithelial differentiation) or pathological processes (e.g. regulation of inflammation, engagement in wound healing) [60-65]. They are also able to remove apoptotic corpses [41, 48, 66]. Professional phagocytes possess a battery of apoptotic-cell surface ligands and intermediate molecules that can lead to uptake of apoptotic cells (AC). Although amateur phagocytes like fibroblasts contribute to AC efferocytosis, mechanisms are not well understood.

We have recently demonstrated that horizontal DNA transfer can occur through the uptake of apoptotic HPV positive cancer cells by human primary fibroblasts (HPFs) leading to their transformation [48]. In the current study, by using the same in vitro co-culture approach, we confirm that HPFs take up late apoptotic cancer cells and we demonstrate that internalization depends to a significant extent on BAI1. Interestingly, HPFs discriminate precisely between viable (data not shown), dying apoptotic targets (EAC) and dead cells (LAC) and mainly engulf LAC and not dying whole cells in contrast to professional phagocytes as macrophages $[67,68]$. This is in line with observations having reported that other amateur phagocytes also preferentially engulf apoptotic bodies [40, 42-44, 52]. As reported earlier [43, 44, 52], the AC uptake by HPF phagocytes occurs more slowly and less efficiently than by professional phagocyte macrophages (Figure 2E). These data corroborate those obtained with endothelial and peritoneal mesothelial cells, as non-professional phagocytes, exhibiting a limited internalization potential compared to macrophages [42-44]. In addition, the relatively long-time sequential events observed using position-referenced microscopy, suggest that upon first tethering, AC uptake by HPFs requires a critical extended recognition and transduction period that triggers actin cytoskeleton remodeling for efferocytosis. Accordingly, this hypothesis has ever been suggested from other amateur phagocytes [42, 52]. To our knowledge, the molecular mechanisms underlying this delay remain elusive.

Confocal microscopy analyses reveal that the internalization process involves the typical sequence of phagosome formation (cup-shaped invaginations of the plasma membrane, that subsequently close at their distal 
margins to form intracellular membrane-bounded organelles) largely mediated by an active actin cytoskeleton remodeling (Figure $2 \mathrm{~F}$ ) even if macropinocytosis cannot be excluded as observed by specific restructuring of the actin cytoskeleton such as membrane ruffles (Figure 2Fc) [35, 69]. Indeed the partial inhibition of AC uptake by dimethylamiloride (Figure 3A) that affects neither phagocytosis nor clathrin or raft-dependent endocytosis suggests that macropinosomes might proceed to AC clearance which agrees with several authors $[15,68-70]$. In addition, the data obtained with cytochalasin D confirm the involvement of actin driven-phagocytosis and likely -macropinocytosis in LAC internalization (Figure 3A). In macrophages typically driving phagocytosis of apoptotic bodies, it has been demonstrated that macropinocytosis could participate in AC uptake in a PtdSerdependent manner (reviewed in Ref. [36]). Thus, in our model, two engulfment mechanisms, phagocytosis and macropinocytosis, might interplay for the removal of apoptotic material. Participation of clathrin-mediated endocytosis might contribute to LAC uptake as documented by the results of our chlorpromazine experiments. However, the low reduction of LAC internalization might also be explained by side effects of that chemical on other endocytic pathways. Indeed, chlorpromazine can interfere with the formation of phagosomes or macropinosomes (reviewed in Ref. [71]), likely because of the clathrin-actin crosstalk [72].

The first step to remove AC requires to distinguish viable cells from dying cells. The flipping of membrane lipids that occurs during early stages of apoptosis results in their exposure on the outer leaflet of the plasma membrane where they can be recognized by phagocytes [14]. Here, the use of annexin V, an inhibitor for PtdSer-mediated efferocytosis, demonstrates that the exposure of PtdSer on the outer leaflet of the AC-plasma membrane is a key event for $\mathrm{AC}$ recognition and subsequent uptake by HPFs (Figure 3B,C). Nevertheless, EAC which also expose PtdSer (Figure 1C) remain weakly engulfed (Figure 2A,B, C, D). It seems clear that PtdSer exposure is required but not sufficient for the target cells to be engulfed by macrophages [67, 73, 74]. As suggested by Borisenko et al., levels of exposed PtdSer above the phagocyte sensitivity threshold might be necessary to allow an efficient apoptotic cell engulfment [75]. When the plasma membrane of AC becomes permeabilized (i.e., in late apoptotic cells), additional molecules are revealed to shape a new combination of 'eatme' and 'don't-eat-me' signals [76], which might favor an optimal apoptotic cell engulfment by HPFs.

Our data also demonstrate that engulfment of apoptotic cancer cells is $\mathrm{Ca}^{2+}$-dependent, since this process is inhibited following the chelation of extracellular $\mathrm{Ca}^{2+}$ by EDTA. They also indicate that engulfment is significantly inhibited at $4^{\circ} \mathrm{C}$. It is noteworthy that these two conditions were reported to inhibit AC-tethering step that subsequently prevent AC uptake by macrophages [77]. Since integrins are known to be inactive at $4^{\circ} \mathrm{C}$, 
we may suggest a role for these cell adhesion receptors in the tethering of apoptotic cells by our amateur phagocytes likely by the MFG-E8-TSP1- $\alpha \mathrm{v} 33$ or $\alpha v ß 5$ through indirect interaction with PtdSer [41, 78, 79].

In 2007, TIM-4 and BAI1 have been identified in macrophages as direct phagocytic receptors for PtdSerexposing apoptotic corpses $[19,21]$. Interestingly, our data demonstrate here that BAI1 receptor was expressed by both HPFs and macrophages contrary to TIM-4 which expression is restricted to macrophages (Figure D). Moreover, siRNA-mediated knockdown of BAI1 in our HPFs cause a significant reduction of BAI1 mRNA associated with a reduction of efferocytosis ability (Figure 3H), as already shown in a model of astrocytes [21]. Together, the present results highlight the involvement of PtdSer recognition in AC efferocytosis and the role of BAI1 as a key PtdSer receptor in our amateur phagocytes. The actin cytoskeletal remodeling observed by confocal microscopy during LAC engulfment (Figure 4F) is likely the consequence of an activation of the ELMO/Dock180/Rac1 pathway by interaction with the intracellular domain of BAI1 [21]. However, our experiments highlight that both PtdSer-masking and BAI1 siRNA lead to partial reduction of AC clearance, suggesting that recognition of apoptotic cells by HPFs may also be triggered by other molecules. One of the potentially involved molecules may be the fibroblast vitronectin receptor [41]. While vitronectin receptor is defined as an integrin receptor triggering thrombospondin-mediated clearance of $\mathrm{AC}[41,80]$, it has also been reported that this phagocytic receptor is attracted to PtdSer through indirect interactions via the bridge molecules MFG-E8 [78, 79]. The formed protein complex has been shown to bind the ELMO/Dock180/Rac1 signaling complex. Thus BAI1 and vitronectin receptor signaling seem intimately interconnected. This apparent redundancy supports the idea of a complex recognition network that may explain why the identification of cell surface proteins involved in the removal of apoptotic cells by non-professional phagocytes has been found to be challenging.

Ingested cellular material can be degraded following maturation of macroendocytic vacuoles through fusion of early endosomes, late endosomes and lysosomes [81]. Here, we further evidence that maturation of AC-containing vacuole is associated with changes in the composition of their membranes as shown by the detection of LAMP-1, a specific marker of lysosomes (Figure 4B). Interestingly, LAMP-1 colocalizes with the key autophagy-related protein LC3 (Figure 4B). Florey et al. have recently uncovered a non-canonical activity of this autophagy protein that is associated with macroendocytic engulfment $[55,82]$. During this process, so-called LC3-associated phagocytosis (LAP), LC3 is directly lipidated onto a variety of single-membrane compartments such as AC-containing vacuoles $[25,55]$. In professional phagocytes, Martinez et al. have suggested that direct LC3 recruitment onto the phagosome membrane promotes phagosome maturation and subsequent degradation of 
445 the engulfed AC [25]. In our knowledge, it is the first time that LAP is observed in amateur phagocytes.

446 However its significance in the clearance of LAC and the possible altered intracellular processing, especially in 447 the context of horizontal gene transfer, remain to be clarified. The identification of other elements of the 448 engulfment machinery expressed by HPFs and the characterization of their function in clearance of AC are 44 beyond the scope of our future investigations. 


\section{Acknowledgments:}

452 We thank Gwenael Rolin, Marion Tissot, Mélanie Couturier for kindly providing human primary fibroblasts and 453 human monocytes-derived macrophages. Authors are grateful to Virginie Mougey (Plateau technique Imagerie 454 Cellulaire et Tissulaire, FED4234, Besançon), Francis Bonnefoy, Julie Frejaville, Sylvie Fauconnet, Aurélie 455 Baguet, Oliver Florey (Babraham Institut, Cambridge) for their technical help and advice. We thank Fiona 


\section{References:}

459 1. Flannagan RS, Jaumouille V, Grinstein S. The cell biology of phagocytosis. Annu Rev Pathol. 2012;7:61-98. doi: 10.1146/annurev-pathol-011811-132445. PubMed PMID: 21910624.

461 2. Underhill DM, Goodridge HS. Information processing during phagocytosis. Nat Rev Immunol. 2012;12(7):492-502. doi: 10.1038/nri3244. PubMed PMID: 22699831.

463 3. Savill J, Fadok V. Corpse clearance defines the meaning of cell death. Nature. 2000;407(6805):784-8. doi: 10.1038/35037722. PubMed PMID: 11048729.

4. Fadok VA, Bratton DL, Henson PM. Phagocyte receptors for apoptotic cells: recognition, uptake, and consequences. J Clin Invest. 2001;108(7):957-62. doi: 10.1172/JCI14122. PubMed PMID: 11581295; PubMed Central PMCID: PMC200959.

5. Erwig LP, Henson PM. Clearance of apoptotic cells by phagocytes. Cell Death Differ. 2008;15(2):24350. doi: 10.1038/sj.cdd.4402184. PubMed PMID: 17571081.

6. Hochreiter-Hufford A, Ravichandran KS. Clearing the dead: apoptotic cell sensing, recognition, engulfment, and digestion. Cold Spring Harb Perspect Biol. 2013;5(1):a008748. doi: 10.1101/cshperspect.a008748. PubMed PMID: 23284042; PubMed Central PMCID: PMC3579390. receptors regulate tolerance against apoptotic cells, and autoantibodies against these receptors are predictive of systemic lupus. J Exp Med. 2007;204(10):2259-65. doi: 10.1084/jem.20070600. PubMed PMID: 17893199; PubMed Central PMCID: PMC2118440. 8. Fadok VA, Bratton DL, Guthrie L, Henson PM. Differential effects of apoptotic versus lysed cells on macrophage production of cytokines: role of proteases. J Immunol. 2001;166(11):6847-54. PubMed PMID: 11359844.

9. Fadok VA, Bratton DL, Konowal A, Freed PW, Westcott JY, Henson PM. Macrophages that have ingested apoptotic cells in vitro inhibit proinflammatory cytokine production through autocrine/paracrine mechanisms involving TGF-beta, PGE2, and PAF. J Clin Invest. 1998;101(4):890-8. doi: 10.1172/JCI1112. PubMed PMID: 9466984; PubMed Central PMCID: PMC508637. 
11. Lauber K, Blumenthal SG, Waibel M, Wesselborg S. Clearance of apoptotic cells: getting rid of the corpses. Mol Cell. 2004;14(3):277-87. PubMed PMID: 15125832.

12. Mevorach D, Mascarenhas JO, Gershov D, Elkon KB. Complement-dependent clearance of apoptotic cells by human macrophages. J Exp Med. 1998;188(12):2313-20. PubMed PMID: 9858517; PubMed Central PMCID: PMC2212421.

13. Fadok VA, de Cathelineau A, Daleke DL, Henson PM, Bratton DL. Loss of phospholipid asymmetry and surface exposure of phosphatidylserine is required for phagocytosis of apoptotic cells by macrophages and fibroblasts. J Biol Chem. 2001;276(2):1071-7. doi: 10.1074/jbc.M003649200. PubMed PMID: 10986279.

14. Fadok VA, Voelker DR, Campbell PA, Cohen JJ, Bratton DL, Henson PM. Exposure of phosphatidylserine on the surface of apoptotic lymphocytes triggers specific recognition and removal by macrophages. J Immunol. 1992;148(7):2207-16. PubMed PMID: 1545126.

15. Hoffmann PR, deCathelineau AM, Ogden CA, Leverrier Y, Bratton DL, Daleke DL, et al. Phosphatidylserine (PS) induces PS receptor-mediated macropinocytosis and promotes clearance of apoptotic cells. J Cell Biol. 2001;155(4):649-59. doi: 10.1083/jcb.200108080. PubMed PMID: 11706053; PubMed Central PMCID: PMC2198875.

16. Krahling S, Callahan MK, Williamson P, Schlegel RA. Exposure of phosphatidylserine is a general feature in the phagocytosis of apoptotic lymphocytes by macrophages. Cell Death Differ. 1999;6(2):183-9. doi: 10.1038/sj.cdd.4400473. PubMed PMID: 10200565.

17. Fadok VA, Bratton DL, Frasch SC, Warner ML, Henson PM. The role of phosphatidylserine in recognition of apoptotic cells by phagocytes. Cell Death Differ. 1998;5(7):551-62. doi: 10.1038/sj.cdd.4400404. PubMed PMID: 10200509.

18. Fadok VA, Bratton DL, Rose DM, Pearson A, Ezekewitz RA, Henson PM. A receptor for phosphatidylserine-specific clearance of apoptotic cells. Nature. 2000;405(6782):85-90. doi: 10.1038/35011084. PubMed PMID: 10811223.

19. Kobayashi N, Karisola P, Pena-Cruz V, Dorfman DM, Jinushi M, Umetsu SE, et al. TIM-1 and TIM-4 glycoproteins bind phosphatidylserine and mediate uptake of apoptotic cells. Immunity. 2007;27(6):927-40. doi: 10.1016/j.immuni.2007.11.011. PubMed PMID: 18082433; PubMed Central PMCID: PMC2757006.

20. Park D, Hochreiter-Hufford A, Ravichandran KS. The phosphatidylserine receptor TIM-4 does not mediate direct signaling. Curr Biol. 2009;19(4):346-51. doi: 10.1016/j.cub.2009.01.042. PubMed PMID: 19217291. 

receptor for apoptotic cells upstream of the ELMO/Dock180/Rac module. Nature. 2007;450(7168):430-4. doi: 10.1038/nature06329. PubMed PMID: 17960134. 22. Park SY, Jung MY, Lee SJ, Kang KB, Gratchev A, Riabov V, et al. Stabilin-1 mediates phosphatidylserine-dependent clearance of cell corpses in alternatively activated macrophages. J Cell Sci. 2009;122(Pt 18):3365-73. doi: 10.1242/jcs.049569. PubMed PMID: 19726632.

23. Park SY, Jung MY, Kim HJ, Lee SJ, Kim SY, Lee BH, et al. Rapid cell corpse clearance by stabilin-2, a membrane phosphatidylserine receptor. Cell Death Differ. 2008;15(1):192-201. doi: 10.1038/sj.cdd.4402242. PubMed PMID: 17962816.

24. Miyanishi M, Tada K, Koike M, Uchiyama Y, Kitamura T, Nagata S. Identification of Tim4 as a phosphatidylserine receptor. Nature. 2007;450(7168):435-9. doi: 10.1038/nature06307. PubMed PMID: 17960135

25. Martinez J, Almendinger J, Oberst A, Ness R, Dillon CP, Fitzgerald P, et al. Microtubule-associated protein 1 light chain 3 alpha (LC3)-associated phagocytosis is required for the efficient clearance of dead cells. Proc Natl Acad Sci U S A. 2011;108(42):17396-401. doi: 10.1073/pnas.1113421108. PubMed PMID: 21969579 ; PubMed Central PMCID: PMC3198353.

26. Flannagan RS, Canton J, Furuya W, Glogauer M, Grinstein S. The phosphatidylserine receptor TIM4 utilizes integrins as coreceptors to effect phagocytosis. Mol Biol Cell. 2014;25(9):1511-22. doi: 10.1091/mbc.E13-04-0212. PubMed PMID: 24623723; PubMed Central PMCID: PMC4004599.

27. Stephenson JR, Purcell RH, Hall RA. The BAI subfamily of adhesion GPCRs: synaptic regulation and beyond. Trends Pharmacol Sci. 2014;35(4):208-15. doi: 10.1016/j.tips.2014.02.002. PubMed PMID: 24642458; PubMed Central PMCID: PMC4029589.

28. Cork SM, Van Meir EG. Emerging roles for the BAI1 protein family in the regulation of phagocytosis, synaptogenesis, neurovasculature, and tumor development. J Mol Med (Berl). 2011;89(8):743-52. doi: 10.1007/s00109-011-0759-x. PubMed PMID: 21509575; PubMed Central PMCID: PMC3152611.

29. Kaur B, Brat DJ, Devi NS, Van Meir EG. Vasculostatin, a proteolytic fragment of brain angiogenesis inhibitor 1, is an antiangiogenic and antitumorigenic factor. Oncogene. 2005;24(22):3632-42. doi: 10.1038/sj.onc.1208317. PubMed PMID: 15782143.

30. Kaur B, Cork SM, Sandberg EM, Devi NS, Zhang Z, Klenotic PA, et al. Vasculostatin inhibits intracranial glioma growth and negatively regulates in vivo angiogenesis through a CD36-dependent mechanism. 

Central PMCID: PMC2659670.

31. Hochreiter-Hufford AE, Lee CS, Kinchen JM, Sokolowski JD, Arandjelovic S, Call JA, et al. Phosphatidylserine receptor BAI1 and apoptotic cells as new promoters of myoblast fusion. Nature. 2013;497(7448):263-7. doi: 10.1038/nature12135. PubMed PMID: 23615608; PubMed Central PMCID: PMC3773542.

32. Kuhn S, Geyer M. Formins as effector proteins of Rho GTPases. Small GTPases. 2014;5:e29513. doi: 10.4161/sgtp.29513. PubMed PMID: 24914801; PubMed Central PMCID: PMC4111664. 33. Pollard TD. Regulation of actin filament assembly by Arp $2 / 3$ complex and formins. Annu Rev Biophys Biomol Struct. 2007;36:451-77. doi: 10.1146/annurev.biophys.35.040405.101936. PubMed PMID: 17477841. 34. Campellone KG, Welch MD. A nucleator arms race: cellular control of actin assembly. Nat Rev Mol Cell Biol. 2010;11(4):237-51. doi: 10.1038/nrm2867. PubMed PMID: 20237478; PubMed Central PMCID: PMC2929822. 35. Swanson JA. Shaping cups into phagosomes and macropinosomes. Nat Rev Mol Cell Biol. 2008;9(8):639-49. doi: 10.1038/nrm2447. PubMed PMID: 18612320; PubMed Central PMCID: PMC2851551. 36. Krysko DV, D'Herde K, Vandenabeele P. Clearance of apoptotic and necrotic cells and its immunological consequences. Apoptosis. 2006;11(10):1709-26. doi: 10.1007/s10495-006-9527-8. PubMed PMID: 16951923. 37. Henry RM, Hoppe AD, Joshi N, Swanson JA. The uniformity of phagosome maturation in macrophages. J Cell Biol. 2004;164(2):185-94. doi: 10.1083/jcb.200307080. PubMed PMID: 14718518; PubMed Central PMCID: PMC2172341.

38. Kinchen JM, Ravichandran KS. Phagosome maturation: going through the acid test. Nat Rev Mol Cell Biol. 2008;9(10):781-95. doi: 10.1038/nrm2515. PubMed PMID: 18813294; PubMed Central PMCID: PMC2908392.

39. Rogers LD, Foster LJ. The dynamic phagosomal proteome and the contribution of the endoplasmic reticulum. Proc Natl Acad Sci U S A. 2007;104(47):18520-5. doi: 10.1073/pnas.0705801104. PubMed PMID: 18006660; PubMed Central PMCID: PMC2141809. 40. Dini L, Lentini A, Diez GD, Rocha M, Falasca L, Serafino L, et al. Phagocytosis of apoptotic bodies by 
41. Hall SE, Savill JS, Henson PM, Haslett C. Apoptotic neutrophils are phagocytosed by fibroblasts with participation of the fibroblast vitronectin receptor and involvement of a mannose/fucose-specific lectin. J Immunol. 1994;153(7):3218-27. PubMed PMID: 7522254.

42. Monks J, Rosner D, Geske FJ, Lehman L, Hanson L, Neville MC, et al. Epithelial cells as phagocytes: apoptotic epithelial cells are engulfed by mammary alveolar epithelial cells and repress inflammatory mediator release. Cell Death Differ. 2005;12(2):107-14. doi: 10.1038/sj.cdd.4401517. PubMed PMID: 15647754.

43. Patel VA, Lee DJ, Feng L, Antoni A, Lieberthal W, Schwartz JH, et al. Recognition of apoptotic cells by epithelial cells: conserved versus tissue-specific signaling responses. J Biol Chem. 2010;285(3):1829-40. doi: 10.1074/jbc.M109.018440. PubMed PMID: 19910463; PubMed Central PMCID: PMC2804341.

44. Wagner BJ, Lindau D, Ripper D, Stierhof YD, Glatzle J, Witte M, et al. Phagocytosis of dying tumor cells by human peritoneal mesothelial cells. J Cell Sci. 2011;124(Pt 10):1644-54. doi: 10.1242/jcs.078907. PubMed PMID: 21525033.

45. Viegas MS, Estronca LM, Vieira OV. Comparison of the kinetics of maturation of phagosomes containing apoptotic cells and IgG-opsonized particles. PLoS One. 2012;7(10):e48391. Epub 2012/11/03. doi: 10.1371/journal.pone.0048391

PONE-D-12-19932 [pii]. PubMed PMID: 23119002; PubMed Central PMCID: PMC3485219.

46. Bergsmedh A, Szeles A, Henriksson M, Bratt A, Folkman MJ, Spetz AL, et al. Horizontal transfer of oncogenes by uptake of apoptotic bodies. Proc Natl Acad Sci U S A. 2001;98(11):6407-11. doi: 10.1073/pnas.101129998. PubMed PMID: 11353826; PubMed Central PMCID: PMC33481.

47. Ehnfors J, Kost-Alimova M, Persson NL, Bergsmedh A, Castro J, Levchenko-Tegnebratt T, et al. Horizontal transfer of tumor DNA to endothelial cells in vivo. Cell Death Differ. 2009;16(5):749-57. doi: 10.1038/cdd.2009.7. PubMed PMID: 19219067.

48. Gaiffe E, Pretet JL, Launay S, Jacquin E, Saunier M, Hetzel G, et al. Apoptotic HPV positive cancer cells exhibit transforming properties. PLoS One. 2012;7(5):e36766. doi: 10.1371/journal.pone.0036766. PubMed PMID: 22574222; PubMed Central PMCID: PMC3344932.

49. Grayson W, Taylor LF, Cooper K. Carcinosarcoma of the uterine cervix: a report of eight cases with immunohistochemical analysis and evaluation of human papillomavirus status. Am J Surg Pathol. 2001;25(3):338-47. PubMed PMID: 11224604. 
50. Unger ER, Vernon SD, Hewan-Lowe KO, Lee DR, Thoms WW, Reeves WC. An unusual cervical carcinoma showing exception to epitheliotropism of human papillomavirus. Hum Pathol. 1999;30(4):483-5. PubMed PMID: 10208473.

51. Silva MT. Secondary necrosis: the natural outcome of the complete apoptotic program. FEBS Lett. 2010;584(22):4491-9. doi: 10.1016/j.febslet.2010.10.046. PubMed PMID: 20974143.

52. Parnaik R, Raff MC, Scholes J. Differences between the clearance of apoptotic cells by professional and non-professional phagocytes. Curr Biol. 2000;10(14):857-60. PubMed PMID: 10899007.

53. Galeano ZJ, Sandoz P, Gaiffe E, Launay S, Robert L, Jacquot M, et al. Position-referenced microscopy for live cell culture monitoring. Biomed Opt Express. 2011;2(5):1307-18. doi: 10.1364/BOE.2.001307. PubMed PMID: 21559142; PubMed Central PMCID: PMC3087587.

54. Sanjuan MA, Dillon CP, Tait SW, Moshiach S, Dorsey F, Connell S, et al. Toll-like receptor signalling in macrophages links the autophagy pathway to phagocytosis. Nature. 2007;450(7173):1253-7. doi: 10.1038/nature06421. PubMed PMID: 18097414.

55. Florey O, Kim SE, Sandoval CP, Haynes CM, Overholtzer M. Autophagy machinery mediates macroendocytic processing and entotic cell death by targeting single membranes. Nat Cell Biol. 2011;13(11):1335-43. doi: 10.1038/ncb2363. PubMed PMID: 22002674; PubMed Central PMCID: PMC3223412.

56. Alvarez-Dominguez C, Roberts R, Stahl PD. Internalized Listeria monocytogenes modulates intracellular trafficking and delays maturation of the phagosome. J Cell Sci. 1997;110 ( Pt 6):731-43. PubMed PMID: 9099947.

57. Tjelle TE, Lovdal T, Berg T. Phagosome dynamics and function. Bioessays. 2000;22(3):255-63. doi: 10.1002/(SICI)1521-1878(200003)22:3<255::AID-BIES7>3.0.CO;2-R. PubMed PMID: 10684585.

58. Hirchaud F, Hermetet F, Ablise M, Fauconnet S, Vuitton DA, Pretet JL, et al. Isoliquiritigenin induces caspase-dependent apoptosis via downregulation of HPV16 E6 expression in cervical cancer Ca Ski cells. Planta Med. 2013;79(17):1628-35. doi: 10.1055/s-0033-1350956. PubMed PMID: 24214831.

59. Ivanov AI. Pharmacological inhibition of endocytic pathways: is it specific enough to be useful? Methods Mol Biol. 2008;440:15-33. doi: 10.1007/978-1-59745-178-9_2. PubMed PMID: 18369934. 60. Driskell RR, Watt FM. Understanding fibroblast heterogeneity in the skin. Trends Cell Biol. 2015;25(2):92-9. doi: 10.1016/j.tcb.2014.10.001. PubMed PMID: 25455110. 
61. Kalluri R, Zeisberg M. Fibroblasts in cancer. Nat Rev Cancer. 2006;6(5):392-401. doi: 10.1038/nrc1877. PubMed PMID: 16572188.

62. Parsonage G, Filer AD, Haworth O, Nash GB, Rainger GE, Salmon M, et al. A stromal address code defined by fibroblasts. Trends Immunol. 2005;26(3):150-6. doi: 10.1016/j.it.2004.11.014. PubMed PMID: 15745857; PubMed Central PMCID: PMC3121558.

63. Tomasek JJ, Gabbiani G, Hinz B, Chaponnier C, Brown RA. Myofibroblasts and mechano-regulation of connective tissue remodelling. Nat Rev Mol Cell Biol. 2002;3(5):349-63. doi: 10.1038/nrm809. PubMed PMID: 11988769 .

64. Chiarugi P. Cancer-associated fibroblasts and macrophages: Friendly conspirators for malignancy. Oncoimmunology. 2013;2(9):e25563. doi: 10.4161/onci.25563. PubMed PMID: 24319632; PubMed Central PMCID: PMC3850271.

65. Madar S, Goldstein I, Rotter V. 'Cancer associated fibroblasts'--more than meets the eye. Trends Mol Med. 2013;19(8):447-53. doi: 10.1016/j.molmed.2013.05.004. PubMed PMID: 23769623.

66. Holmgren L, Szeles A, Rajnavolgyi E, Folkman J, Klein G, Ernberg I, et al. Horizontal transfer of DNA by the uptake of apoptotic bodies. Blood. 1999;93(11):3956-63. Epub 1999/05/26. PubMed PMID: 10339505.

67. Cocco RE, Ucker DS. Distinct modes of macrophage recognition for apoptotic and necrotic cells are not specified exclusively by phosphatidylserine exposure. Mol Biol Cell. 2001;12(4):919-30. Epub 2001/04/11. PubMed PMID: 11294896; PubMed Central PMCID: PMC32276.

68. Xu W, Roos A, Schlagwein N, Woltman AM, Daha MR, van Kooten C. IL-10-producing macrophages preferentially clear early apoptotic cells. Blood. 2006;107(12):4930-7. Epub 2006/02/25. doi: 2005-10-4144 [pii] 10.1182/blood-2005-10-4144. PubMed PMID: 16497970.

69. Krysko DV, Denecker G, Festjens N, Gabriels S, Parthoens E, D'Herde K, et al. Macrophages use different internalization mechanisms to clear apoptotic and necrotic cells. Cell Death Differ. 2006;13(12):201122. doi: 10.1038/sj.cdd.4401900. PubMed PMID: 16628234.

70. Ogden CA, deCathelineau A, Hoffmann PR, Bratton D, Ghebrehiwet B, Fadok VA, et al. C1q and mannose binding lectin engagement of cell surface calreticulin and CD91 initiates macropinocytosis and uptake of apoptotic cells. J Exp Med. 2001;194(6):781-95. PubMed PMID: 11560994; PubMed Central PMCID: PMC2195958.

71. Dutta D, Donaldson JG. Search for inhibitors of endocytosis: Intended specificity and unintended consequences. Cell Logist. 2012;2(4):203-8. Epub 2013/03/30. doi: 10.4161/cl.23967 

2013;140(15):3230-43. Epub 2013/07/19. doi: 10.1242/dev.093732 140/15/3230 [pii]. PubMed PMID: 23861060; PubMed Central PMCID: PMC3931732.

73. Devitt A, Pierce S, Oldreive C, Shingler WH, Gregory CD. CD14-dependent clearance of apoptotic cells by human macrophages: the role of phosphatidylserine. Cell Death Differ. 2003;10(3):371-82. Epub 2003/04/18. doi: 10.1038/sj.cdd.4401168

4401168 [pii]. PubMed PMID: 12700637.

74. Segawa K, Suzuki J, Nagata S. Constitutive exposure of phosphatidylserine on viable cells. Proc Natl Acad Sci U S A. 2011;108(48):19246-51. Epub 2011/11/16. doi: 10.1073/pnas.1114799108 1114799108 [pii]. PubMed PMID: 22084121; PubMed Central PMCID: PMC3228483.

75. Borisenko GG, Matsura T, Liu SX, Tyurin VA, Jianfei J, Serinkan FB, et al. Macrophage recognition of externalized phosphatidylserine and phagocytosis of apoptotic Jurkat cells--existence of a threshold. Arch Biochem Biophys. 2003;413(1):41-52. Epub 2003/04/23. doi: S0003986103000833 [pii]. PubMed PMID: 12706340.

76. Poon IK, Hulett MD, Parish CR. Molecular mechanisms of late apoptotic/necrotic cell clearance. Cell Death Differ. 2010;17(3):381-97. Epub 2009/12/19. doi: 10.1038/cdd.2009.195

cdd2009195 [pii]. PubMed PMID: 20019744.

77. Dransfield I, Zagorska A, Lew ED, Michail K, Lemke G. Mer receptor tyrosine kinase mediates both tethering and phagocytosis of apoptotic cells. Cell Death Dis. 2015;6:e1646. Epub 2015/02/20. doi: $10.1038 /$ cddis. 2015.18

cddis201518 [pii]. PubMed PMID: 25695599.

78. Hanayama R, Tanaka M, Miwa K, Shinohara A, Iwamatsu A, Nagata S. Identification of a factor that links apoptotic cells to phagocytes. Nature. 2002;417(6885):182-7. Epub 2002/05/10. doi: 10.1038/417182a 417182a [pii]. PubMed PMID: 12000961.

79. Borisenko GG, Iverson SL, Ahlberg S, Kagan VE, Fadeel B. Milk fat globule epidermal growth factor 8 (MFG-E8) binds to oxidized phosphatidylserine: implications for macrophage clearance of apoptotic cells. Cell Death Differ. 2004;11(8):943-5. Epub 2004/03/20. doi: 10.1038/sj.cdd.4401421 4401421 [pii]. PubMed PMID: 15031725. 

receptor in macrophage recognition of neutrophils undergoing apoptosis. J Clin Invest. 1992;90(4):1513-22. Epub 1992/10/01. doi: 10.1172/JCI1 16019. PubMed PMID: 1383273; PubMed Central PMCID: PMC443198. 81. Zhou Z, Yu X. Phagosome maturation during the removal of apoptotic cells: receptors lead the way. Trends Cell Biol. 2008;18(10):474-85. Epub 2008/09/09. doi: 10.1016/j.tcb.2008.08.002 S0962-8924(08)00211-0 [pii]. PubMed PMID: 18774293; PubMed Central PMCID: PMC3125982. 2012;22(7):374-80. doi: 10.1016/j.tcb.2012.04.005. PubMed PMID: 22608991; PubMed Central PMCID: 
703 Figure Legends:

$704 \quad$ Figure 1: Generation of early and late apoptotic cancer cells.

$705 \mathrm{HeLa}$ and Ca Ski cells were exposed to $20 \mathrm{~mJ} / \mathrm{cm}^{2}$ dose of UV irradiation and $300 \mathrm{nM}$ staurosporine for 6 or 48

706 h. (A) For Sub-G1 analysis, cells were fixed, washed and incubated with PI for 15 min. The intracellular PI fluorescence intensities of 20,000 cells were measured in each sample using flow cytometry. Data shown are representative of 3 independent assays in triplicate. (B) Nuclear fragmentation was observed by fluorescent microscopy after DAPI (blue) staining. All panels were photographed at X40 and scaled to the same size. Fluorescent microscopic images are representative of 3 independent assays. Bar $=30 \mu \mathrm{m}$. (C) Early apoptosis and late apoptosis were respectively assessed by a simple cell staining with annexin $\mathrm{V}$ and a double cell staining with annexin V and PI detected by flow cytometry. The ratio of EAC and LAC (\%) are indicated in the given quadrant. Data shown are

representative

of 3 independent assays in triplicate. 
Figure 2: Uptake of apoptotic cells by HPFs occurs in a time- and stage-dependent manner.

(A) The binding and uptake of PKH67-labeled HeLa EAC and LAC (green) by HPFs (left and middle panel respectively) or $\mathrm{M} \varphi$ (right panel) was investigated by confocal microscopy after incubation for $6 \mathrm{~h}$ at $37^{\circ} \mathrm{C}$. Nonlabeled HPFs or M $\varphi$ were co-cultured with PKH67-labeled apoptotic cells (AC) at a phagocyte cell/target ratio of 1:10, followed by washing to remove the non-ingested apoptotic cells. The nuclei and actin cytoskeletons of fixed HPFs or M $\varphi$ and apoptotic targets were respectively stained with DAPI (blue) and TRITC-conjugated phalloidin (red). All panels were photographed at a X40 magnification and scaled to the same size. Fluorescent microscopic images are representative of 3 independent assays. Bar $=60 \mu \mathrm{m}$. (B) Based on the fluorescent microscopic analyses after $2 \mathrm{~h}$ and $6 \mathrm{~h}$ of co-culture, more than 200 HPFs were scored as described in "Material and Methods" to determine the percentage of engulfed HeLa AC- (left panel) or Ca Ski AC- (right panel) phagocytosing (means \pm SD). (C) For analysis by flow cytometry, PKH67-labeled HeLa EAC and LAC (green) and PKH26-labeled (red) adherent HPFs were cultured separately (upper row) or in a 10:1 ratio for $6 \mathrm{~h}$ at $37^{\circ} \mathrm{C}$ (lower row). Flow cytometry acquisition was performed as described in "Material and Methods". Co-culture assays show that HPFs became positive for PKH67. The percentage of HPFs that were phagocytosing was determined as described in "Material and Methods". Representative dot plots are shown for HPFs and HeLa AC. (D) As depicted in C, quantitative analyses (means \pm SD) of apoptotic HeLa cell (left panel) or Ca Ski cell (right panel) phagocytosis by HPFs after 2 and $72 \mathrm{~h}$ of co-culture at a 10:1 ratio were performed from 3 experiments in triplicate. (E) Uptake kinetics of LAC by HPFs and M $\varphi$ were investigated by confocal microscopy starting from $2 \mathrm{~h}$ of co-culture and phagocytosis was evaluated as depicted in B. (F) The morphological analysis of the uptake of HeLa LAC by HPFs was investigated by confocal microscopy as depicted in A. All panels were photographed at a X60 magnification and scaled to the same size. Bar $=10 \mu \mathrm{m}$. (G) To illustrate engulfment of a HeLa LAC (arrow) by HPFs, a sequence of images were obtained by position-referenced microscopy from a co-culture between CFSE-labeled (green) HeLa LAC and PKH26-labeled (red) adherent HPFs observed at time intervals 
Figure 3: Involvement of phosphatidylserines and BAI1 receptor in the uptake of late apoptotic cells by

\section{HPFs.}

(A) PKH26-labeled HPFs were incubated at $4^{\circ} \mathrm{C}$ or preincubated or not with EDTA, cytochalasin D, DMA, chlorpromazine or nystatin at $37^{\circ} \mathrm{C}$ for $1 \mathrm{~h}$ before the co-culture with PKH67-labeled apoptotic cells for $6 \mathrm{~h}$ at $4^{\circ} \mathrm{C}$ or $37^{\circ} \mathrm{C}$. Uptake was quantified by flow cytometry as depicted in Figure $2 \mathrm{C}$. These data (means \pm SD) represent the relative uptake against the control (untreated cells). (B) PKH67-labeled apoptotic or viable cells were preincubated with or without unlabeled annexin V at RT for 30 min before incubation with PE annexin V in darkness at RT for 20 min and cytometry analysis. Data show the dose-dependent PtdSer masking of HeLa (left panel) or Ca Ski (right panel) late apoptotic cells by annexin V preincubation. The graphs are representative of 3 independent experiments in triplicate. (C) PKH67-labeled apoptotic cells were preincubated with or without unlabeled annexin V at RT for 20 min before the co-culture with PKH26-labeled HPFs. Based on cytometry analyses, the data (means $\pm \mathrm{SD}$ ) represent the relative uptake against the control (untreated cells) and show the inhibitory effect of PtdSer masking on HeLa (left panel) or Ca Ski (right panel) apoptotic cell engulfment. (D) The relative expression of BAI1 and TIM-4 PtdSer mRNA in HPFs and M $\varphi$ was assessed by RT-qPCR. (E) For analysis of the subcellular localization of BAI1 by confocal microscopy, HPFs were cultured separately (upper row). $\mathrm{M} \varphi$ that demonstrate strong membranous staining for BAI1 were used as positive control cells (lower row). Indirect immunofluorescence studies using anti-BAI1 antibody (H270; Alexa Fluor 488 signal, green), TRITC-conjugated phalloidin staining of F-actin (red) and DAPI staining (blue) were performed. All panels were photographed at a X40 magnification and scaled to the same size. Bar $=50 \mu \mathrm{m}$. (F) HPFs were cultured with PKH67-labeled HeLa LAC (green) in a 1:10 ratio for $6 \mathrm{~h}$ at $37^{\circ} \mathrm{C}$. Indirect immunofluorescence studies using anti-BAI1 antibody (H270; Cy3 signal, red) and DAPI staining (blue) were performed. All panels were photographed at a X60 magnification and scaled to the same size. Bar $=30 \mu \mathrm{m}$. (G) (H) PKH26-labeled HPFs were transfected with BAI1 siRNA or control siRNA. Two days after siRNA transfection, (G) relative RNA quantification of the relative BAI1 contents in siRNA-treated cells were performed, and PKH26-labeled HPFs were co-cultured with late apoptotic HeLa or Ca Ski cells. (H) Based on cytometry analyses, the data (means \pm SD) represent the relative uptake of siRNA BAI1 and siRNA control transfected HPFs against the control (untreated HPFs) and show that HPFs transfected with BAI1 siRNA demonstrated a lower ability to internalize

control. 
Figure 4: The uptake of late apoptotic cells by HPFs induces LC3 lipidation onto the phagocytic vacuoles.

770

771

772

773

774

775

776

777

778

779

780

(A) Immunoblot of LC3 and beta actin was performed to evaluate LC3 lipidation in HPFs after $24 \mathrm{~h}$ co-culture at a ratio of 10:1 at $37^{\circ} \mathrm{C}$ with LAC HeLa and Ca Ski. HPFs were used as controls. The values of the densitometric analysis were normalized and expressed as fold increase. (B) The colocalisation of LC3 (Alexa Fluor 488 signal, green) and LAMP1 (Cy3 signal, red) to the membrane of Cell Proliferation Dye eFluor ${ }^{\circledR}$ 450-labeled (violet) HeLa LAC -containing vacuole in HPFs after $24 \mathrm{~h}$ of co-culture at a ratio of $10: 1$ at $37^{\circ} \mathrm{C}$ was analyzed by confocal microscopy. HPF images were captured as controls. All panels were photographed at a X40 magnification and scaled to the same size. Fluorescent microscopic images are representative of 3 independent assays. Bar $=20 \mu \mathrm{m}$. (C) The graphs display the colocalisation of the fluorescence signals, given in arbitrary fluorescence units (AFU), for the HeLa LAC (violet AFU) and the phagosome membrane proteins (LC3, green $A F U$; LAMP1, red $A F U$ ). The white bars in the pictures show the localization of the cross-section corresponding to the fluorescence diagram within the HPFs. Bar $=20 \mu \mathrm{m}$. 
782 Figure S1: HPF delays ingesting late apoptotic cell for hours after recognizing it.

783 The video combines a sequence of images - obtained by confocal fluorescence microscopy and phase contrast

784 imaging - performed from a co-culture between CFSE-labeled (green) HeLa LAC and PKH26-labeled (red)

785 adherent HPFs observed at time intervals of one hour over $11 \mathrm{~h}$. 
787 Figure S2: The drug-dependent effect on late apoptotic cell uptake by HPFs is independent of cytotoxic 788 effect.

789 HPFs were treated with or without increasing concentrations of cytochalasin D, DMA, chlorpromazine or 790 nystatin at $37^{\circ} \mathrm{C}$ for $7 \mathrm{~h}$, a time condition that mimicks $1 \mathrm{~h}$ of preincubation and $6 \mathrm{~h}$ of co-culture with apoptotic cells. Based on MTT assay, these data (means \pm SD) represent the relative viability against the control (untreated cells) and show that the drug-dependent effect on late apoptotic cell uptake by HPFs is independent of cytotoxic effect. 